\title{
DIE ABORSIEDEBAT IN DIE LIG VAN DIE VERHOUDING TUSSEN REG EN ETIEK
}

\author{
I.J. Kroeze \\ Departement Romeinse Reg en Regspluralisme \\ Potchefstroomse Universiteit vir CHO \\ POTCHEFSTROOM
}

\begin{abstract}
Absiract
In this anticle it is contended that individual arguments regarding abortion are dependent on a few prior questions. The answers given to these questions determine the view that a particular writer has of abortion These questions deal primarily with the nature of law and of ethics respectively and with the relationship between the two. When answering these questions most writers fall in one of two categories. They are of either a posivistic or a natural law persuasion.

In the first section the basic tenets of these two schools of thought are examined. In the second section the various angunents regarding aborion are examined in the light of the answers given in the first section. Il is found that all argumenis rest on implied or explicit preconceived ideas These preconcieved ideas are determined by the way in which a writer sees the relationship between law and morality.

The conclusion is that philosophical ideas determine not only the answers to "philosophical" questions, but also everyday questions such as the legal nules that should be followed in cases of abortions.
\end{abstract}

\section{INI EIDING}

Aborsie was in die loop van eeue nog altyd 'n kontensieuse saak wat gemoedere hoog laat loop het. Vandag is die vraag na die toelaatbaarheid al dan nie van aborsie wêreldwyd steeds 'n strydvraag. Ook in Suid-Afrika was die vraag na die wenslikheid van meer liberale aborsiewetgewing onlangs in die nuus. Die debat, sowel in Suid-Afrika as in die buiteland, is dikwels emosioneel en etikettering asook verdagmakery kom voor. Die rede vir hierdie emosionaliteit is daarin te vinde dat deelnemers aan die debat voorgee dat hulle argumente rasioneel en waardevry is, terwyl persoonlike waardeoordele 'n definitiewe rol speel. Argumente rondom aborsie staan dus nie los van 'n bepaalde persoon se lewens- en wêreldbeskouing nie, maar word radikaal daardeur beinvloed. Daar gaan in hierdie artikel gepoog word om die verband duideliker te maak.

Sommige skrywers meen dat daar geen verband is tussen 'n standpunt rondom aborsie 
en 'n bepaalde lewens- en wêreldbeskouing nie. Daarom is hulle van mening dat die owerheid sekere reelings met betrekking tot aborsie behoort toe te pas (of nie toe te pas nie) vanuit dit wat die skrywer self as eties goed- of afkeurenswaardig beskou. So 'n benadering ontken egter die eie aard van die reg en van die etiek, aangesien aanvaar word dat die een tot die ander herlei kan word. Gevolglik word belangrike voorvrae na (a) die aard van die reg en van die etiek en (b) na die verhouding tussen reg en etiek geïgnoreer. Dit, op sy beurt, resulteer in etiese relatiwisme. In hierdie artikel word slegs die verhouding tussen reg en etiek ondersoek.

Indien die voorvrae na die verhouding tussen reg en etiek geïgnoreer word en die aborsiedebat bloot gevoer word na aanleiding van persoonlike opinies oor die morele aanvaarbaarheid al dan nie van aborsie, is daar 'n groot gevaar van etiese relatiwisme. Daar moet dus in gedagte gehou word dat opinies bepaal word deur die antwoorde wat, uitdruklik of stilswyend, op bepaalde voorvrae gegee word. Die belangrikste van hierdie voorvrae is dan die vraag na die aard van die reg en van die etiek en die verhouding tussen reg en etiek.

\section{DIE VERHOUDING TUSSEN REG EN ETIEK}

Wanneer die verhouding tussen reg en etiek ter sprake kom, blyk dit dat die meeste skrywers aanhangers van of die natuurreg of die positivisme is. Die belangrikste uitgangspunte van hierdie twee skole word vervolgens kortliks weergegee alvorens argumente rondom aborsie in die lig van hierdie uitgangspunte in die volgende afdeling beoordeel word.

Die natuurreg-benadering vertoon twee verskyningsvorms:

- Eerstens is daar dié benadering wat die natuurregsreëls gelykstel met etiese beginsels. Hierdie benadering is afkomstig van Thomas van Aquino en die Skolastici (Thomas, Summa 2.1.90.1 en 2), en word later deur die Spaanse moraalfilosowe verder gevoer (Suarez, De legibus 2.6). Ook nie-Katolieke skrywers volg hierdie benadering. Die uitgangspunt is dat die ewige, onveranderlike natuurreg bestaan uit etiese reêls. Natuurreg word dus gelykgestel met etiek. Die etiese reels is die norm vir regsreëls (Blackstone, 1809:2.39-40). Regsreëls ontstaan dus uit etiese reëls en is vir hulle voortbestaan afhanklik van hulle ooreenstemming met dié etiese reels (Devlin, 1965:9-11; Buys, 1976:64). Hierdie benadering kan as die enge natuurreg getipeer word.

- Tweedens is daar dié benadering wat ook uitgaan van 'n stel ewige, onveranderlike, universele natuurregsreëls, maar hieruit is sowel etiese beginsels as regsbeginsels af 
te lei (Van der Vyver, 1983a:362-369). Vanuit dié beginsel sal die mens etiese reëls en regsreëls positiveer. Sowel die etiek as die reg se ontstaansbron is dus die natuurreg, maar dan via etiese en regsbeginsels onderskeidelik (Del Vecchio, 1969:7. 8; Cohen, 1950:15,27). Hierdie benadering kan as die wyer natuurreg getipeer word.

Ook die positivisme erken dat daar regsreëls en etiese reēls bestaan en dat dié twee mekaar wedersyds beinvloed. Daar is egter twee verskille tussen die natuurreg en die positivisme.

* Die positivisme erken die bestaan en invloed van etiese reëls, maar ontken dat die gelding van regsreëls ooit afhanklik gemaak kan word van hulle ooreenstemming met etiese reëls (Hart, 1958:599). Regsreëls en etiese reëls het elk 'n aantal vereistes waaraan voldoen moet word voordat dit as sodanig erken kan word (Fuller, 1958:641). Hierdie vereistes by regsreëls sluit egter nie etiese gebondenheid in nie. Hiermee word die enger natuurregsbenadering bestry.

- Die positivisme ontken die bestaan van 'n stel ewige, onveranderlike, universele reëls waaraan regsreëls getoets moet word. Daar word ook gesé dat selfs al sou die natuurreg bestaan, dit vir die regswetenskap onbruikbaar is, aangesien die bestaan en inhoud daarvan nie empiries vasstelbaar is nie (Hart, 1961:170-175; Raz, 1979:38-39). Hiermee word die wyer natuurregsbenadering teengestaan.

Wanneer hierdie twee stelsels geëvalueer word, lyk dit op eerste aanblik onversoenbaar. Nadere ondersoek toon egter veel meer ooreenkomste as wat algemeen aanvaar word. In hierdie verband vertoon die wyer benadering van die natuurreg en die positivisme veel meer raakvlakke as in die geval van die enger natuurreg.

Die eng benadering ten opsigte van die natuurreg hou vas aan die primaat van etiese reels as die toetssteen van regsreëls. Die aard van die reg is dus dat dit menslike reels is wat in ooreenstemming met die natuurreg (etiese reēls) moet wees. Die aard van die etiek is sinoniem met die aard van die natuurreg. Daar kan dus aanvaar word dat ooreenstemming met etiese reels ' $n$ konstitueringsvereiste vir regsreëls is. Daarom is die verhouding tussen reg en etiek een van interafhanklikheid. Dit is by hierdie fundamentalistiese benadering tot die reg dat die verskille tussen die enger natuurreg en die positivisme die duidelikste na vore kom. Alhoewel Mill ook na 'n "hoogste reg" verwys (Mill, 1859:14), word etiese reels in die positivisme nooit as voorvereistes vir die reg aanvaar nie.

Die wyer benadering van die natuurreg enersyds en die positivisme andersyds is veel nader aan mekaar. Die volgende ooreenkomste kan geïdentifiseer word: 
- Albei erken dat daar 'n verskil met betrekking tot die totstandkoming en inhoud van etiese reëls en regsreëls bestaan.

- Albei erken dat reg en etiek mekaar wedersyds beïnvloed sonder dat die een 'n voorvereiste vir die geldigheid van die ander is.

Die essensiële verskil tussen die wyer natuurreg en die positivisme is geleë in hulle sienings van die aard van die reg.

* Volgens die positivisme is die reg 'n stel reels wat min of meer willekeurig tot stand kom. Daarom meen Habermas dat die reg net deur fisiese, effektiewe mag gesanksioneer word en dat legaliteit en moraliteit fundamenteel teenstellend is (Habermas, 1974:850). Alhoewel daar aan die konstitutiewe en strukturele vereistes voldoen moet word, erken die positivisme geen beperking op die inhoud en omvang van regsreëls nie (Hart, 1958:626). Ook by die beoordeling van die geldigheid van regsreëls speel net formele elemente 'n rol. Regsreëls kan wel gekritiseer word op grond van etiese (en ander) waardes, maar nooit asof dit die geldigheid van die regsreël aantas nie (Mill, 1859:12). Die aard van die reg is dus, volgens die positivisme, vasstelbaar deur te toets of aan die rules of behaviour en rules of recognition voldoen is. Die rules of behaviour is konstitueringsvereistes wat bepaal dat wette op ' $n$ bepaalde manier en deur ' $n$ kompetente wetgewer gemaak moet word. Die rules of recognition bepaal hoe regsreëls moet lyk ten einde as sodanig herken te word (Hart, 1961:113).

- Volgens die natuurreg (in wye sin) is die reg 'n stel reêls wat op formele wyse tot stand kom en wat moet voldoen aan die vereistes wat deur die natuurreg gestel word (Fuller, 1958:645). Die wetgewer se willekeur speel dus nie so 'n groot rol nie, aangesien hy gebonde is aan natuurregsreëls. By die vereistes wat die positivisme stel, vereis die natuurreg dus ook dat die morele waarde van die regsreëls deel uitmaak van die toets om die aard van die reg vas te stel. Hierdie morele waarde van die reg impliseer egter nie dat alle natuurregsgeleerdes die reg en etiek met mekaar gelykstel nie. Van der Vyver meen naamlik dat die constitutive legal principles nie etiese oordele insluit nie, aangesien die aard van die reg deur regsbeginsels bepaal word (Van der Vyver, 1983a:362). Tog vorm die etiese modaliteit die ideaal ten einde van die reg 'n beter reg te maak (Fuller, 1958:645).

Ook wat die aard van die etiek betref, verskil die wyer natuurreg en die positivisme.

- Volgens die wyer natuurreg is die etiese reels, net soos regsreëls, via etiese beginsels uit natuurregsreëls af te lei. Dit impliseer dat sowel regsreëls as (gepositiveerde) etiese reëls aan die vereistes van die natuurregsreëls moet voldoen. 
- Volgens die positivisme is die inhoud van etiese reels nie empiries vasstelbaar nie en daarom nie bruikbaar vir die regswetenskap nie. Daarom word nie ontken dat die etiek die reg beïnvloed nie, maar word gesê dat etiese oordele eers gegiet moet word in die vorm van regsreëls (wat aan al die vereistes wat vir die reg gestel word, voldoen) voordat daarvan kennis geneem kan word (Hart, 1961:31). Die positivisme meen dus wel dat etiese oordele regsreëls beïnvloed, maar bespreek nie wat hierdie oordele behels nie. Cohen aanvaar ook hierdie uitgangspunt, maar wys daarop dat ndg die etiek nog die reg altyd dieselfde is (Cohen, 1950:16). Dit impliseer dat geeneen van die twee as paradigma vir die ander gebruik kan word nie.

Dit is duidelik dat sowel die positivisme as die natuurreg uitgaan daarvan dat die aard van die reg en van die etiek verskil en dat die een nie tot die ander herlei kan word nie. Die implikasie hiervan is dat morele oordele per se nooit in regsreëls vergestalt kan word nie. Dit is eers wanneer so 'n morele oordeel 'n aspek van die taak van die reg betrek dat dit in regsreëls vervat kan word. Indien 'n morele oordeel dus ook binne die werksgebied van die reg val, kan dit as basis vir 'n regsreël dien.

Uit bogenoemde moet egter nie afgelei word dat die feit dat 'n bepaalde regsreēl ook 'n sterk etiese karakter en etiese gevolge het, dit noodwendig beteken dat etiese oordele in regsreëls gepositiveer is nie. Sekere handelinge (soos vertrouensbreuk en onwaarhede) is beide juridies en eties afkeurenswaardig. Die feit dat reg en etiek in sekere omskrewe gevalle, soos by onwaarhede oorvleuel, beteken nie dat die reg etiese reëls oorgeneem het of moet oorneem nie. Die feit dat bepaalde handelinge sowel juridies as eties afkeurenswaardig is, impliseer dat elkeen op tipiese manier (volgens eie aard) deur middel van juridiese en etiese prosesse onderskeidelik die onderskeie gevolge daarvan reel.

Dit impliseer egter ook dat daar sekere handelinge is wat nie sowel juridies as eties afkeurenswaardig is nie. Dit is veral gevalle van die sogenaamde victim'ess crime waar daar nie sprake is van optrede wat eie is aan die aard van die reg nie. Hier is naamlik nie sprake van ' $n$ afweeg en harmonisering van belange nie, aangesien daar geen benadeeldes is nie. ' $n$ Voorbeeld van sulke gevalle is die verbod op Sabbatsontheiliging en pornografie.

Die oplossing vir die probleem van die verhouding tussen reg en etiek is dus te vinde in die eie aard en tipiese werking van die reg en die etiek onderskeidelik. Sowel die reg as die etiek het dus 'n bepaalde funksie om te vervul. Tog kan sekere handelinge (soos byvoorbeeld bedrog) albei in werking stel, omdat dit vir die eie aard van sowel die reg as die etiek onaanvaarbaar is en dus herstel moet word. Dit beteken egter nie dat die regsverbod op bedrog op etiese oordele gebaseer is nie. 


\section{DIE ABORSIEDEBAT}

\subsection{Inleiding}

Daar is reeds melding gemaak van die feit dat deelnemers aan die aborsiedebat dikwels voorgee dat hulle argumente rasioneel en waardevry is. Daar is toe daarop gewys dat standpunte oor aborsie (mede-)bepaal word deur antwoorde wat (eksplisiet of implisiet) op bepaalde voorvrae gegee word. Een van hierdie voorvrae het te make met die verhouding tussen reg en etiek. Die uitgangspunt van 'n bepaalde skrywer, hetsy positivisties, hetsy vanuit die natuurreg, is dus bepalend vir die standpunte wat so 'n skrywer oor aborsie huldig.

Wanneer die standpunte oor aborsie geanaliseer word, is dit duidelik dat dit in twee groepe uiteenval.

* Ten eerste is daar dié groep argumente waar die filosofiese grondslae van die argument of eksplisiet uitgespel word of ten minste duidelik uit die argument blyk.

- Ten tweede is daar die groep argumente wat daarop aanspraak maak dat dit nie op filosofiese gronde berus nie en daarom waardevry is.

Ten opsigte van die eerste groep argumente word gepoog om vas te stel of dié filosofiese grondslae waarmee gewerk word, konsekwent toegepas word. Die vraag is dus of skrywers werklik met die uitgangspunte werk waarmee hulle voorgee om te werk. Die tweede groep argumente word ontleed on vas te stel of dit werklik waardevry is en, indien dit nie die geval is nie, op welke waarde-oordele dit wel berus.

Die basis waarop argumente beoordeel word, is ten eerste die innerlike samehang van argumente. Hiermee word bedoel dat 'n bepaalde argument nie innerlik teenstrydig moet wees nie en ten minste met die uitgangspunt versoenbaar moet wees. Ten tweede word argumente beoordeel op grond van die aanvaarbaarheid al dan nie van die implikasies wat sulke argumente het. Daarom word nie net argumente self beoordeel nie, maar ook die implikasies van sulke argumente, ten einde vas te stel of sulke argumente werklik houdbaar is.

In die loop van hierdie evaluasie word van verskeie terme gebruik gemaak. Die terme liberaal en konsenwatief moet nie in hulle gewone betekenis verstaan word nie. In hierdie verband verwys liberaal na argumente van diegene wat aborsies op baie wye gronde of op aanvraag toegelaat wil hâ. Dit impliseer dat die meeste of alle regverdigingsgronde toegelaat word en/of dat aborsie gedekriminaliseer moet word. Konserwatief verwys na die argumente van diegene wat aborsie op baie eng gronde toegelaat of heeltemal verbied sou wou sien. Dit impliseer dat min of geen regverdigingsgronde 
erken word nie.

Daar word ook in hierdie afdeling verwys na feministiese en patemalistiese argumente. Albei hierdie benaderings berus op 'n bepaalde siening van die taak en die plek van die vrou. Aan die een kant behels die patemalistiese benadering dat vroue nie in staat is om besluite aangaande hulle eie lewens te neem nie. Dit berus dus op 'n houding dat die man as pater moet optree om besluite namens die vrou te neem. Aan die ander kant word hierdie benadering deur die feministe teengestaan op grond van die emansipasie van die vrou. Die vrou word dus gesien as 'n persoon in eie reg wat self aileen besluite oor 'n aborsie kan neem. Argumente binne sowel die paternalistiese as feministiese kader kan ook liberaal of konserwatief wees.

\subsection{Die begin van die lewe}

Die argumente rondom die beginpunt van menslike lewe vorm die basis van heelwat ander argumente. Dit is vir feitlik alle skrywers duidelik dat daar reeds by konsepsie sprake is van lewe, in watter vorm ook al. Die vraag is op watter stadium hierdie lewe aanspraak kan makk op die beskerming wat die reg bied. Aan die een kant word geargumenteer dat menslike lewe moontlik voor geboorte teenwoordig is, maar dat daar eers by geboorte van 'n persoon sprake is (Weiss, 1974:33). Aan die ander kant is daar skrywers wat meen dat daar reeds vanaf konsepsie van lewe wat beskerm moet word sprake is. (Hierdie standpunt word later behandel.)

Die uitgangspunt van eersgenoemde argument is dus dat regsubjektiwiteit by geboorte ontstaan. Hierdie gedagte word oënskynlik gestaaf deur mediese handboeke wat drie kriteria verskaf om te bepaal wanneer die fetus 'n mens word, naamlik lewensvatbaarheid, lewende geboorte en skeiding van die moeder (Schwär, Olivier \& Loubser, 1984:261). Hierdie mediese kriteria word egter meesal aangewend om te bepaal of die kind na geboorte geleef het of nie, en nie om regsubjektiwiteit te bepaal nie. Die bepaling van die aard van die mens en van menslikheid, persoonlikheid en regsubjektiwiteit bly in wese 'n filosofiese vraag (Callahan, 1973:94). Dié filosofiese uitgangspunt word op sy beurt weer (ten minste mede-)bepaal deur teologiese vrae.

Die implikasie van hierdie siening is dat aborsie op enige stadium voor geboorte geregverdig is, aangesien daar nie sprake is van 'n persoon wat beskerm moet word sprake is nie. Dit sou inhou dat 'n aborsie selfs in die agtste maand van swangerskap uitgevoer kan word. Die meeste skrywers en wetgewers is egter nie bereid om hierdie implikasie te aanvaar nie en daarom word meer gematigde standpunte voorgestaan.

Soms word aanvaar dat lewe wel voor geboorte begin, maar nie by konsepsie nie.

Koers 55(4) 1990:423-443 
Daarom sê Kolb (1981:1125): "At, some point ... the fetus develops physiologically to the stage where a united, functioning mind and body exist. At that point abortion would be murder." Gewoonlik word die tydstip waarop lewe begin, gekoppel aan die tydstip van lewensvatbaarheid, gewoonlik om en by die agt-en-twintigste week van swangerskap (Williams, 1958:209). Aborsies wat voor hierdie tyd uitgevoer word, is volgens sommige regstelsels nie wederregtelik nie, aangesien die fetus nie 'n persoon is nie. Hierdie benadering is deur die meeste Europese en Amerikaanse regstelsels gevolg, alhoewel die tydperke wat gestel word, verskil.

Juis die verskil in tydperke wat gestel word - vanaf twaalf weke in Denemarke en Oostenryk tot agt-en-twintig weke in die Verenigde Koninkryk - plaas 'n vraagteken agter die oënskynlike uitgangspunt van lewensvatbaarheid. Terwyl 'n kind wat op agten-twintig weke gebore word met mediese hulp kan oorleef, is dit ondenkbaar dat 'n drie maande-oue fetus kan oorleef. Dit is moontlik dat hierdie siening gekoppel kan word aan houdings met betrekking tot die animasie van die fetus, sodat moderne Rooms-Katolieke geleerdes verklaar dat die fetus 'n mens word tussen die veertiende en die een-en-twintigste dag na konsepsie (Curran, 1982:20).

'n Variasie op bogenoemde argument is 'n poging om die argument "tegnies" te staaf. Daar word aangetoon dat spontane aborsies dikwels in die vroeë maande van swangerskap voorkom. Hierdie aborsies word nie beskou as die dood van 'n mens nie en daar word byvoorbeeld nie 'n begrafnis gehou nie (Williams, 1958:206). Omdat spontane aborsie dus nie as die dood van 'n mens beskou word nie, is daar geen rede om 'n geïnduseerde aborsie as moord te beskou nie.

Teenoor bogenoemde benadering staan die argument wat daarvan uitgaan dat lewe (asook regsubjektiwiteit) by konsepsie begin en dat aborsie daarom moord is (Barnard et al, 1978:345, 349; Heyns, 1985:40; Bertrand, 1977:268). Hierdie benadering berus op die uitgangspunt dat die sanctity of life die hoogste waarde is en daarom altyd beskerm moet word. Hierdie benadering het in die Verenigde State van Amerika tot die sogenaamde Human Life-Amendement tot die VSA Konstitusie gelei, waardeur die fetus tot 'n persoon verklaar word en deur die Konstitusie beskerm word (Copelon, 1981:46). Hierdie amendement is nog nie deur die verlangde aantal state geratifiseer nie en vorm dus nie deel van die Konstitusie nie. Dit is veral vanuit godsdienstige oogpunt dat hierdie argument geregverdig word. Oosthuizen (1974:63) verklaar byvoorbeeld: "Because the foetus is already ' $n$ human being the sixth commandment applies." (Vgl. ook Tarr, 1983:18.)

Die belangrikste implikasie van hierdie argument is dat dit alle regverdigingsgronde, behalwe noodtoestand, uitsluit. Daarmee word veronderstel dat 'n wettige aborsie net uitgevoer kan word in gevalle waar die moeder se lewe in gevaar is. Dit was byvoor- 
beeld die situasie gewees in die Verenigde Koninkryk voor die wysiging van die gemenereg aldaar. Dit is egter duidelik dat hierdie benadering nie vir die gemeenskap aanvaarbaar is nie, veral omdat geen regverdigingsgronde naas noodtoestand erken word nie.

Ten einde die kritiek te akkommodeer, is ' $\mathrm{n}$ variasie op bogenoemde argument aanvaar wat daarvan uitgaan dat, alhoewel regsubjektiwiteit nie noodwendig by konsepsie begin nie, die fetus nietemin 'n beskermenswaardige reg op lewe het (Van der Vyver, 1983b:10; De Blois, 1981:147; Van der Vyver \& Joubert, 1985:72). Op grond hiervan verkry die fetus ' $n$ bepaalde status, indien nie as mens nie, dan as potensiële lewe (Weiss, 1974:34) en as sodanig is die fetus geregtig op beskerming deur die reg.

Hierdie argument verteenwoordig 'n kompromis tussen die uiterste konserwatiewe en liberale benaderings. Daar word (implisiet) aanvaar dat die fetus eers by geboorte 'n persoon met regsubjektiwiteit word, maar dat die fetus reeds vanaf konsepsie 'n beskermbare belang het. Hierdie belang hou (onder andere) in dat dié potensiële lewe nie sonder meer vernietig kan word nie. Dit is ook die de facto-benadering in die SuidAfrikaanse reg.

- Dit is belangrik om daarop te let dat al bogenoemde argumente nie alleen op eksplisiete morele keuses gebaseer is nie, maar ook op implisiete morele keuses rakende die taak van die reg. Alhoewel skrywers met terme werk wat bekend is aan die reg (soos persoon en regsubjektiwiteit), is die inhoud van hierdie terme filosofies bepaald. Gevolglike word van die reg verwag om aborsies te wettig of te verbied op grond van implisiete morele oordele.

Dit is duidelik dat hierdie benadering feitelik in baie regstelsels gevolg word, terwyl daar oënskynlik 'n ander benadering gevolg word. Die probleem met dié benadering is egter dat die aard en omvang van die beskermbare belang nie omskryf ivord nie. Daar bestaan dus geen maatstaf waaraan regverdigingsgronde gemeet kan word nie. Regverdigingsgronde word willekeurig erken sonder dat die filosofiese grondslae of basis waarop dit berus ooit uitgespel word.

\subsection{Quality of life vs Sanctity of life}

Daar is reeds vermeld dat die konserwatiewe benadering ten opsigte van aborsie in 'n groot mate steun op die houding dat lewe by konsepsie begin, en dat hierdie lewe heilig is en daarom deur die reg beskerm moet word. Hierdie benadering staan bekend as die sanctity of life-benadering. Daar word aangevoer dat die liberale benadering die waarde van menslike lewe as sodanig ondergrawe (Bertrand, 1977:268; Bar- 
nard et al, 1978:344). Benewens die heiligheid van menslike lewe word ook aanvaar dat alle lewens ewe veel werd is (Tarr, 1983:18). Omdat alle lewens dieselfde waarde het, is daar geen regverdiging daarvoor dat een lewe vir 'n ander opgeoffer word nie.

Hier is eintlik twee benaderings ter sprake. Aan die een kant is daar die siening van Tarr (1983:18) wat impliseer dat die moeder se lewe nie meer of minder werd is as die fetus s'n nie, en gevolglik is dit glad nie vanselfsprekend dat die fetus geaborteer word as die moeder se lewe in gevaar is nie. Die implikasie is dus dat daar geen regverdigingsgronde erken word nie, aangesien dit nooit aanvaarbaar is om 'n menslike lewe te neem nie. Aan die ander kant is daar die meer gematigde uitgangspunt dat lewe wel heilig is, maar dat tog voorsiening gemaak word vir gevalle van noodtoestand. Hierdie benaderings sluit dus nou an by die konserwatiewe argument wat hierbo by die begin van lewe genoem is.

In teenstelling met bogenoemde is daar die argument wat lui dat die vraag na die begin van menslike lewe irrelevant is, aangesien die kwaliteit van menslike lewe belangriker is as die blote feit dat lewe wel teenwoordig is (Copelon, 1981:72). Dit is die sogenaamde quality of life-benadering. Dié standpunt impliseer dat aborsie toelaatbaar is wanneer die geboorte die kwaliteit van lewe van die fetus (of van 'n ander persoon) sou aantas. Ook waar die lewenstandaard van ander kinders in die gesin aangetas sou word, is aborsie volgens hierdie benadering toelaatbaar. Copelon (1981:72) stel dit soos volg: "Maybe life doesn't begin at birth, but it doesn't end there either."

Albei hierdie standpunte het belangrike implikasies. Die sanctity of life-benadering hou in wese in dat die voorstanders daarvan geen regverdigingsgronde, benewens noodtoestand, kan goedkeur nie. Indien die lewe heilig is en alle lewens dieselfde waarde het, kan daar geen verskil wees tussen die fetus wat byvoorbeeld deur verkragting verwek is en dié een wat binne ' $n$ huwelik verwek is nie - daarom sal die voorstanders van hierdie benadering nie aborsies na verkragting goedkeur nie. Net so, omdat die waarde van alle menslike lewe dieselfde is, kan die aborsie van gestremde of misvormde fetusse nie goedgekeur word nie (Heyns, 1985:44). Die uiteindelike implikasie is dan dat geen regverdigingsgronde benewens noodtoestand goedgekeur word nie.

Ook die quality of life-benadering het 'n onvoorsiene gevolg. Dit is die uitgangspunt van hierdie benadering dat aborsies toelaatbaar is in alle situasies waar die kwaliteit van die lewe ter sprake is. Dit impliseer dat die neem van 'n lewe in hierdie omstandighede dan geregverdig is. Alhoewel die voorstanders van hierdie standpunt dié gevolg waarskynlik nie voorsien nie, is dit moontlik dat so 'n benadering tot 'n Hitlermentaliteit kan lei waar alle lewe wat die kwaliteit van ander se lewens bedreig, geneem kan word. Die benadering hou dus die gevaar van die minagting van lewe in al 
sy verskyningsvorms in

Albei hierdie argumente is ook op eksplisiete morele oordele gebaseer. Die probleem met albei standpunte is egter dat dit selde konsekwent toegepas kan word. 'n Regstelsel wat byvoorbeeld sanctity of life as uitgangspunt neem, sal ook die doodstraf moet verbied en gekant wees teen oorlog, aangesien een lewe nie meer werd is as 'n ander nie. Die quality of life-benadering sou weer binne 'n regstelsel die gevolg hê dat genadedood en volksmoord geregverdig kan word.

\subsection{Menseregte en godsdiensvryheid}

Die grootste teenstand teen 'n liberale aborsiebeleid het nog altyd van die kant van die kerke gekom. Die Gereformeerde Ekumeniese Sinode (GES) het reeds sy teenstand teen aborsie uitgespreek op grond van die mens se rigth to life (RES, 1983:151). In hierdie verband sluit die GES aan by die siening van Toth dat daar 'n higher law bestaan wat aborsies verbied (Toth, 1985:42). Hierdie benadering gaan dus uit van die veronderstelling dat die fetus, as unbom human being, 'n reg op lewe het wat deur Goddelike wette daargestel is (RES, 1983:151).

As uitvloeisel van bogenoemde word dikwels aanspraak gemaak op die Christelike leer van menseregte en word aangevoer dat aborsie in stryd daarmee is (De Blois, 1981:148). Net so word aangevoer dat aborsies in stryd is met die klassieke teorie van menseregte (Glenn, 1975:80).

Alhoewel bogenoemde standpunt deur 'n groot aantal Christene aanvaar word, bied dit slegs op 'n deel van die probleem 'n antwoord. Skrywers wys daarop dat die persoonlike opinie oor die goed- of afkeurenswaardigheid van aborsie nie noodwendig impliseer dat die owerheid hierdie opinies in wetgewing moet vergestalt nie. Inteendeel, daar word beweer dat ' $n$ liberale aborsiebeleid die enigste is wat met godsdiensvryheid versoenbaar is. Hierdie argument berus op die veronderstelling dat die besluit om 'n aborsie te ondergaan 'n saak is waaroor elke vrou self moet besluit en dat nog die kerk nòg die owerheid die reg moet hê om hierdie gewetensbesluit namens haar te neem (Buys, 1976:64).

Die siening van die Rooms-Katolieke kerk in die verband is interessant. Terwyl hulle steeds gekant is teen aborsie, verklıar Aartsbiskop Hurley: "If the majority in a society wants abortion on demand, churches will not prevent its legalisation." (Hurley, 1974:77.) Dit is interessant dat twee standpunte, wat op die eerste aanblik onversoenbaar lyk, uiteindelik dieselfde effek kan hê. Dit dui egter op die belangrike verskil tussen persoonlike opinies en die siening van die owerheid se taak met betrekking tot 
wetgewing oor aangeleenthede met etiese implikasies.

Die standpunte wat hierbo genoem is, is die enigstes wat eksplisiet melding maak van die verskil tussen reg en etiek. Daar word dus aanvaar dat dit nie die taak van die owerheid is om etiese oordele per se toe te pas nie. Aborsie word dan beskou as etiese oordele wat nie deur die owerheid afgedwing moet word nie.

\subsection{Paternalisme en feminisme}

Seker die sterkste stukrag agter die pogings tot liberalisering van die aborsiebeleid was die feministiese beweging van die sestiger- en sewentigerjare (Middleton, 1972:397). Meesal was die beweegrede hieragter 'n bekommernis oor die lewe en gesondheid van vroue wat agterstraat- (of onwettige) aborsies ondergaan (Kunst \& Meiring, 1984:264) Daar is egter ook 'n ander, meer teoretiese rede waarom 'n liberale aborsiebeleid beskou word as die enigste wat met die feminisme versoenbaar is. Copelon (1983:146) stel dit soos volg: "Without the ability to decide whether and when to bear children, women lack a prerequisite to equality." Die filosofiese rede vir bogenoemde stelling is soos volg deur Steinem opgesom: "... if the patriarchal state, church and family lose their control over women's bodies as the most basic means of production ... those structures eventually will be more democratic and not patriarchal at all" (Steinem, 1981:44). 'n Mate van beheer oor biologiese prosesse word dus deur hierdie groep bepleit (Callahan, 1973:100).

Dit is belangrik om op die redenasie agter hierdie standpunt te wys. Daar word geargumenteer dat dit ' $n$ voorvereiste vir die bevryding van vroue is dat hulle beheer sal hê oor hul eie liggame en die biologiese prosesse wat daarmee verband hou. Wat egter verswyg word, is die aannames wat hierdie argument voorafgaan. Indien aborsie gesien word as 'n manier van beheer oor die vrou se eie liggaam, is die aanname dat die fetus gesien word as 'n deel van die vrou se liggaam en nie as 'n afsonderlike entiteit nie. Die implikasie is dus dat die fetus net so deel is van die vrou as haar arm of been en dat sy dus daarmee kan maak wat sy wil. Wanneer hierdie aanname eers duidelik is, is dit meteen ook duidelik dat die feministe se primêre uitgangspunt is dat lewe by geboorte begin. Die fetus is dus deel van die vrou totdat dit gebore word en daarom is aborsie toelaatbaar.

Die feministiese argument berus op twee aannames. Ten eerste word aanvaar dat die fetus eers by geboorte ' $n$ persoon word. Dit sluit dus aan by argumente rondom die begin van lewe en betrek ook aspekte van die quality of life-benadering. Ten tweede word aanvaar dat owerheidsinmenging tot 'n minimum beperk moet word. Dié aanname sluit aan by die argumente rondom godsdiensvryheid. Die afdwinging van wat ge- 
sien word as suiwer morele oordele word dus nie as deel van die taak van die reg beskou nie.

In teenstelling met bogenoemde benadering word soms op paternalistiese wyse geargumenteer dat vroue onbevoeg is om self ' $n$ keuse met betrekking tot die morele goed- of afkeurenswaardigheid van aborsie te maak (Humber, 1976:75). Hierdie argument berus op die aanname dat vroue minderwaardig en te emosioneel is om self oor so 'n belangrike saak te besluit.

Hierdie benadering, wat volgens feministe aan die wortel van die konserwatiewe benadering le, het ook bepaalde implikasies. Dit impliseer dat vroue ook nie in staat is om besluite oor ander aspekte van hulle biologiese funksies te neem nie en dat die owerheid dus sulke besluite moet neem. Dit sou byvoorbeeld die gevolg kon hê dat die owerheid besluit wanneer ' $n$ vrou kinders moet hê en hoeveel kinders sy behoort te hê. So 'n staatsabsolutistiese houding is die noodwendige uitvloeisel van die ontkenning van vrouens se vermoë om self besluite oor morele kwessies te neem. Hierdie benadering gaan dus daarvan uit dat dit (ook) die taak van die reg is om morele besluite vir individue te neem.

\subsection{Gemeenskapsopinie}

Een van die potensieel gevaarlikste argumente rondom aborsie het te make met die rol wat die meerderheidsopinie speel in die aborsiedebat. Daar word geargumenteer dat die gemeenskap oorwegend ten gunste is van 'n meer liberale aborsiebeleid en daarom behoort wetgewing in lyn met gemeenskapsopinie gebring te word (Kunst \& Meiring, 1984:264). Hierdie opinie word versterk deur koerantberigte (Anon, 1985:9) en wetenskaplike studies (RGN, 1980).

Hierdie argument is gevaarlik om twee redes. Ten eerste moet daar nie te maklik aanvaar word dat die meerderheid ' $n$ bepaalde opinie huldig nie. Behalwe dat gemeenskapsopinie relatief vinnig kan verander, is daar altyd die sogenaamde stilswyende meerderheid, oftewel die moral majority waarop die Amerikaanse Pro Life-beweging hom beroep. Dit kan tot 'n groot mate van regsonsekerheid lei, aangesien die wetgewing moet verander telkens wanneer die gemeenskapsopinie verander of 'n nuwe studie aantoon wat die gemeenskapsopinie oor ' $n$ bepaalde saak is. Ten tweede berus hierdie argument op 'n bepaalde siening van die taak van die reg, naamlik dat die reg die wil van die gemeenskap (of ten minste die meerderheid in die gemeenskap) moet weerspieël (Armstrong, 1973:253; S v King 1971 2 PH H 103 (T). Die probleem hiermee is dat die inhoud van morele waardes bepaal word deur die meerderheid in die gemeenskap en die meerderheid van mense bepaal dan ook wat reg is. Met ander 
woorde: die meerderheid is altyd reg, oftewel: mag is reg.

\subsection{Onwettige aborsic en realisme}

Daar word dikwels geargumenteer dat 'n liberale aborsiebeleid sal dien om die wetgewing in ooreenstemming met die werklikheid te bring. Liberale aborsiewetgewing sal dus meer realisties wees (Kunst \& Meiring, 1984:265). In dié verband word gewoonlik gewys op die groot aantal aborsies wat ten spyte van beperkende wetgewing (wat met strafsanksies gepaard gaan) plaasvind (Steinem, 1981:44; Armstrong, 1973:252). Daar word na beraming jaarliks sowat 200000 onwettige aborsies in SuidAfrika uitgevoer (Golembo, 1985:7). Hiermee wil voorstanders van hierdie beleid dit duidelik maak dat die konserwatiewe benadering gefaal het in sy poging om aborsies te stop (Anon, 1985:7). Ferreira is daarvan oortuig dat die wettiging van aborsie die getal onwettige aborsies sal laat daal (Ferreira, 1985:55).

Ook hierdie benadering berus op 'n bepaalde siening van die taak van die reg. Hier word aanvaar dat indien 'n regsnorm nie meer aan sy doel beantwoord nie, dit afgeskaf behoort te word (Duvenage, 1971:32). Legaliteit en effektiwiteit word dus as sinonieme beskou. Dit is egter onrealisties om te verwag dat 'n wet, net omdat dit dikwels oortree word, afgeskaf moet word. Die onvoorsiene implikasie van so 'n standpunt sou wees dat die verbod op die verkoop van dagga opgehef moet word net omdat 200000 persone jaarliks dagga verkoop. Daar kan dus nie verwag word dat blote effektiwiteit die deurslaggewende faktor vir die behoud of afskaffing van regsreëls moet wees nie.

In reaksie op bogenoemde argument wys die voorstanders van 'n konserwatiewe aborsiebeleid daarop dat liberaler wetgewing in ander lande nie tot 'n afname in die getal onwettige aborsies gelei het nie (Middleton, 1972:400). Ook hierdie argument berus op die benadering dat die effektiwiteit van wetgewing die belangrikste kriterium behoort te wees. Hier word net die liberale wetgewing getoets om te bepaal of dit aan die gestelde doelwit beantwoord. Ook in hierdie geval kan die effektiwiteit van wetgewing nie op sigself dien as kriterium vir die aanvaarbaarheid van wetgewing nie.

Dit is onrealisties om te verwag dat onwettige aborsies ooit geheel en al sal verdwyn. Daar sal steeds situasies wees waarin vrouens verkies om 'n aborsie onwettig te laat doen vanweë godsdienstige of ander druk. Wat wel waar is, is dat vroue wat na 'n onwettige aborsie probleme ontwikkel, makliker hulp sal soek indien aborsies nie geheel en al verbied is nie. Daarom is 'n liberale aborsiebeleid waarskynlik wel effektief om die mortaliteit van vrouens by onwettige aborsies te laat daal (Middleton, 1972:399). Ook hier is effektiwiteit dus die deurslaggewende faktor. 


\subsection{Aborsie en oorbevolking}

Een van die grootste probleme waarmee die wêreld te kampe het, is oorbevolking. Die konserwatiewe benadering is dat die probleem van ongewenste swangerskappe waarskynlik ten beste opgelos kan word deur voorkomende maatreëls soos effektiewe seksonderrig en die vrye beskikbaarheid van voorbehoedmiddels (Armstrong, 1973:253). Daarom is die primêre oplossing nie aborsie nie, maar die voorkoming van swangerskap (Ellis, 1974:45).

Alhoewel die uitgangspunt van bogenoemde argument aanvaarbaar is, is die praktiese uitwerking daarvan ' $n$ groot probleem. Benewens die feit dat so 'n benadering heelwat finansiële steun benodig, is dit 'n langtermynprojek waarvan die sukses nie gewaarborg is nie. Intussen kom ongewenste swangerskappe steeds voor.

Vir hierdie en ander redes word aborsie dikwels gesien as 'n oplossing vir die oorbevolkingsprobleem. Aborsies vir hierdie doel is dan ook binne die Islam-geloof toelaatbaar (Nadvi, 1974:49). Demograwe meen ook dat die probleem van oorbevolking nie deur die gebruik van voorbehoedmiddels alleen opgelos kan word nie en dat aborsies 'n belangrike rol kan speel om vrugbaarheid te beperk (Ferreira, 1985:57; Sarvis \& Rodman, 1974:147-151).

Dit is interessant dat van die liberaalste aborsiewetgewing voorkom in lande waar oorbevolking 'n groot probleem is, byvoorbeeld China, Japan en Indie. Dit dui daarop dat die beperking van oorbevolking deur middel van aborsie in hierdie lande as noodsaaklik beskou word. Dit dui verder daarop dat hierdie argument op suiwer pragmatiese doelstellings gerig is. Daar word geen oordeel gevel oor die morele goedof afkeurenswaardigheid van aborsie nie, maar dit word bloot aanvaar dat dit 'n effektiewe oplossing vir die probleem van oorbevolking is.

'n Ander rede waarom voorbehoedmiddels en seksonderrig alleen waarskynlik nie die probleem van oorbevolking kan oplos nie, word in Suid-Afrika gevind. Een van die onvoorsiene gevolge van die apartheidsbeleid is dat swart vroue wantrouig is oor voorbehoedmiddels. Dit is die gevolg van aparte gesondheidsdienste vir swart en wit, sodat swart vroue nooit sien dat wit vroue ook voorbehoedmiddels gebruik nie. As gevolg hiervan word voorbehoedmiddels gesien as 'n poging van blankes om swart getalle te verminder en so dié potensiële swart magsbasis te vernietig. Aborsie is in hierdie situasie die enigste uitweg in gevalle van ongewenste swangerskap (Ferreira, 1980:58; Sarvis \& Rodman, 1974:160).

'n Argument waarna reeds in die vorige paragraaf verwys is, is afkomstig uit die swart gemeenskap. In terme van hierdie benadering word aborsie teengestaan omdat dit 
swart getalle sal verminder en daarom swart politieke aspirasies sal verydel. Sibisi (1974:58) verklaar soos volg: "(I)t is also wrong national planning for deprived and underprivileged peoples; for their strength lies in their numbers." Aborsie word dus teengestaan op grond daarvan dat dit gesien word as 'n poging deur blankes om die getalle van swartes te beheer (Ferreira, 1985:58). Dié siening is nie tot Suid-Afrika beperk nie, maar vind ook uiting in die Verenigde State van Amerika, waar vrese van 'n black genocide geopper word, aangesien verreweg die meeste fetusse wat geaborteer word van swart moeders afkomstig is (Sarvis \& Rodman, 1974:173).

Ook hierdie argumente is gebaseer op 'n bepaalde siening van die taak van die reg. Die reg word gesien as 'n instrument om sosiale veranderinge mee te bring (aborsies word byvoorbeeld toegelaat om bevolkingsaanwas te keer) of om nie sosiale en politieke verandering in die weg te staan nie (aborsies word byvoorbeeld verbied om bevolkingsaanwas te bevorder). In albei gevalle is die reg dus ' $n$ instrument van social engineering. Hierdie is 'n uiterste voorbeeld van 'n positivistiese houding wat die morele inhoud van wetgewing total ignoreer en slegs let op die doel wat met wetgewing bereik moet word.

\subsection{Die gevolge van aborsie}

'n Groep argumente handel nie oor aborsie of die regverdigingsgronde as sodanig nie. 'n Argument wat dikwels gebruik word om aan te toon dat die konserwatiewe benadering ongewens is, gaan om die posisie van ongewenste kinders wat gebore word. So sê Williams (1958:199): "Lack of parental love for the unwanted child is not merely a tragedy in the child's early youth; it is one of the major predisposing factors to juvenile delinquency, and so can lead to a ruined career." Hieraan word toegevoeg: "But we cannot force her to want a child and whatever is compelled ... against the will or contra mentum is not moral ..." (Hall, 1970:94.)

Hierdie probleem word vererger deur die feit dat 'n groot persentasie van ongewenste swangerskappe onder tieners voorkom (Wallis, 1985:39). Daar word bereken dat 30000 tieners onder die ouderdom van 15 jaar in die Verenigde State van Amerika swanger word en dat $40 \%$ van alle veertienjariges ten minste eenmaal sal swanger word voor die ouderdom van twintig jaar. Tieners wat seksueel aktief is, het dikwels nie die nodige kennis van voorbehoeding nie of het geen toegang tot voorbehoedmiddels nie. Aborsie is dan die uitweg om die effek van die gebrek aan kennis en niebeskikbaarheid van voorbehoedmiddels ongedaan te maak.

Net soos die voorafgaande argument, word soms geargumenteer dat die liberale houding met betrekking tot aborsie onaanvaarbaar is, omdat die gevolge van aborsies 
onaanvaarbaar is (Steenberg, 1985:5). Die voorstanders van hierdie argument wys op die fisiese sowel as die psigiese gevolge van die aborsie vir die vrou self en dui veral op sielkundige probleme as gevolg van skuldgevoelens. Teenstanders van hierdie argument (Ferreira, 1985:57 en Williams, 1958:189) dui egter daarop dat waar aborsies nie verbode is nie en dus geen stigma dra nie, hierdie probleem nie noodwendig voorkom nie.

'n Ander moontlike gevolg van 'n liberaler aborsiebeleid is die ontwikkeling van 'n aborsie-mentaliteit in 'n bepaalde land (Ferreira, 1985:58). Dit hang saam met die moontlikheid dat die waarde van lewe as sodanig ondergrawe word. In hierdie verband word geargumenteer dat 'n samelewing se houding ten opsigte van aborsie 'n aanduiding is van die respek wat so 'n samelewing vir die lewe het (Callahan, 1973:89).

Albei hierdie benaderings poog om 'n mening oor aborsie te vorm sonder om die morele vrae rondom aborsie te bespreek. Daar word dus melding gemaak van ongewenste kinders sonder dat aborsie as sodanig bespreek word. Dit is dus 'n pragmatiese benadering wat bloot na die effektiefste oplossing vir die probleem van ongewenste swangerskappe sock. Die tweede benadering is ook op pragmatisme gebou. Daar word dus gevra welke benadering effektief sou wees binne psigologiese en sosiologiese verband. Die benadering wat hieraan voldoen, word voorgestaan. Terselfdertyd word nie melding gemaak van die psigologiese effek en sosiologiese probleme van ongewenste swangerskappe nie.

\subsection{Samevatting}

Wanneer die verskillende argumente bestudeer word, word dit duidelik dat hulle in twee groepe ingedeel kan word.

Ten eerste is daar die argumente wat gebou word rondom die vraag of die fetus 'n persoon is of nie. Die antwoord wat op laasgenoemde vraag gegee word, bepaal die houding van die betrokke skrywer met betrekking tot aborsie. In hierdie groep val alle argumente rondom die heiligheid van die lewe, die beginpunt van lewe asook menseregte-argumente wat op die personaliteit van die fetus gebou word. Hierdie argumente word gewoonlik op eksplisiete morele oordele gebou aangesien skrywers bewustelik 'n bepaalde morele standpunt inneem vanwaar verder geargumenteer word.

Ten tweede is daar dié argumente wat nie die vraag na die personaliteit van die fetus betrek nie. Hierdie argumente word op ander faktore gebou, soos gemeenskapsopinie of ideologiese oorwegings. Meesal is hierdie argumente pragmaties van aard en word net gevra na die effektiefste oplossing vir bepaalde probleme. Die argumente wat in 
hierdie groep val, gee gewoonlik voor om waardevry te wees maar werk in werklikheid met implisiete vooroordele. Die bestudering van hierdie argumente dui daarop dat geeneen van hierdie benaderings waardevry is nie, maar dat almal op die een of ander filosofiese basis gebou is, hetsy in die vorm van morele oordele, hetsy in die vorm van pragmatiese of ideologiese standpuntinnames.

Dit is egter interessant dat die meeste van die argumente (indien nie almal nie) op kompromieë berus. Die ekstreme argumente rondom die beginpunt van lewe word byvoorbeeld getemper sodat skrywers erken dat regsubjektiwiteit nie by geboorte begin nie, maar terselfdertyd word aan die fetus 'n beskermenswaardige belang toegeken asof daar reeds voor geboorte van 'n persoon sprake is. Op dié wyse word die probleme rondom die konserwatiewe benadering omseil sonder om in die slaggate van die liberale benadering te trap. Net so word die sanctity of life-beginsel in die Suid-Afrikaanse reg as uitgangspunt gebruik, terwyl in die wetgewing ook regverdigingsgronde gevind word wat op die quality of life-beginsel gegrond is. Artikel 3(1)(c) van die Wet op Vrugafdrywing en Sterilisasie 2 van 1975 maak byvoorbeeld voorsiening vir die afdryf van 'n misvormde fetus. Dit is 'n duidelike voorbeeld van 'n regverdigingsgrond wat op die kwaliteit van lewe van die fetus gebou is.

'n Belangrike neiging wat ten opsigte van die aborsiedebat waargeneem word, is die groeiende tendens om argumente op pragmatiese grondslae te bou. Hiermee word bedoel dat die morele goed- of afkeurenswaardigheid van aborsie glad nie behandel word nie, maar dat slegs gevra word na die effektiefste oplossing vir 'n probleem, hetsy aborsie self, hetsy verbandhoudende probleme soos oorbevolking, ongewenste swangerskappe of politieke doelwitte. Skrywers wat hierdie benadering voorstaan, gee dus voor dat hulle oordele waardevry is, aangesien morele oordele nie gevel word nie. Die skynbare afwesigheid van morele oordele waarborg egter nie dat 'n betrokke standpunt waardevry is nie. Die besluit ten gunste van 'n pragmatiese benadering is op sigself ' $n$ waarde-oordeel en verteenwoordig 'n benadering tot morele probleme wat poog om die moraliteit self te omseil. Om hierdie rede is so 'n benadering onaanvaarbaar.

\section{GEVOLGTREKKING}

Die bestudering van die aborsiedebat bring 'n aantal probleme na vore wat wêreldwyd, asook in Suid-Afrika, relevant is. Hiervan is veral twee tans belangrik:

- Ten eerste is dit duidelik dat geeneen van die argumente waardevry is nie. Dit bevat telkens voorwetenskaplike oordele, hetsy eksplisiet, hetsy implisiet. Aangesien dit duidelik is dat voorvrae 'n rol speel, behoort hierdie voorvrae duidelik uitgespel en beantwoord te word. Die eerste stap in die oplossing van die aborsieprobleem is 
dus om die voorvrae te identifiseer en te beantwoord.

- Ten tweede is dit duidelik dat selfs waar van eksplisiete morele oordele gebruik gemakk word, hierdie uitgangspunte selde konsekwent toegepas word. Die aborsieprobleem sal dus net opgelos kan word indien die vereistes van logika en die innerlike samehang van standpunte in die oog gehou word.

Die aborsiedebat moet dus nie primêr gevoer word na aanleiding van bepaalde standpunte oor aborsie nie, maar ook oor die voorvrae wat van belang is. Daarom word ' $n$ tweestadiumbenadering voorgestaan. Ten eerste moet die voorvrae geïdentifiseer word en 'n standpunt daaroor geformuleer word. In die Suid-Afrikaanse konteks sal dus bepaal moet word wat die standpunt is oor die taak van die reg en van die etiek onderskeidelik en oor die verhouding tussen die twee. Ten tweede sal die antwoord wat op dié voorvrae gegee is, bepalend wees vir die filosofiese standpunt wat as basis vir die aborsiebeleid gebruik word en sal die aborsiewetgewing in terme van hierdie uitgangspunt hersien moet word.

Indien dié voorgestelde benadering in Suid-Afrika toegepas sou word, sou dit tot verskillende resultate (afhangende van die beantwoording van die voorvrae) lei. Indien die Suid-Afrikaanse wetgewer besluit om 'n positivistiese benadering ten opsigte van die taak van die reg te volg, kan morele oordele geen rol speel by die bepaling van die beleid ten opsigte van aborsie nie. Dan kan die beleid op pragmatiek en effektiwiteit gebaseer word. Indien egter besluit word dat die reg en etiek wel oorvleuel, moet besluit word watter uitgangspunt gevolg gaan word (byvoorbeeld sanctity of life of quality of life) en hierdie uitgangspunt moet konsekwent nagevolg word. Dit sou impliseer dat indien die sanctity of life-benadering gevolg word, geen uitsonderings op die verbod op aborsie toegelaat word nie. Indien die quality of llfebenadering egter gevolg word, kan aborsie feitlik op aanvraag toegestaan word. Hieruit blyk dat die keuse om of 'n positivistiese of 'n natuurregsbenadering te volg, ' $n$ wesenlike invloed uitoefen op die aborsiebeleid wat toegepas word. Die antwoorde wat op voorvrae gegee word, bepaal dus welke argumente aanvaarbaar is.

Hieruit blyk dat die filosofiese uitgangspunte van skrywers 'n definitiewe uitwerking het op die tipe wetgewing wat voorgestaan word. Die vereiste bly egter steeds dat hierdie uitgangspunte duidelik uitgespel en konsekwent toegepas word.

\section{BIBLIOGRAFIE}

ANONIEM. 1985. Vroue bankvas vir nuwe aborsiewelgewing. Beeld: 9, April. 10.

ARMSTRONG. N.W. 1973. The new aborlion bill - medicine and sociely. Responsa Meridiana: 2(4):247. 254 
BARNARD, T.A., DU PLESSIS, L.M., KEMPF, G. \& OOSTHUIZEN, G. 1978. Aborsie: 'n juridiese, etiese en regsetiese vraagstuk. Koers, 43(4):330-350.

BERTRAND, A.R.L. 1977 \& 1978. The Aborion and Sterilisation Act 2 of 1975: a third opinion. SuidAfrikaanse Tydsknf vir Sirafreg en Kriminologie, 1(1):263-285; 2(2):263-277.

BLACKSTONE W. 1809. Commentaries on the laws of England. London : Strahan.

BUYS, P.W. 1976. Abortion. (In Buys, P.W. 1976. Contemporary Ethical Problems. Kaapstad)

CALLAHAN, D. 1973. Abortion: some ethical issues (In Walbert, D.F. \& Butler, J.D. ed. Abortion, society and the law. Cleveland : Press of Case Western Reserve University. p. 89-102.)

COHEN, M.R. 1950. Reason and law. Glencoc, Illinois : Free Press.

COPELON, R. 1981. Danger: a human life amendement is on the way. $M s, 1 X: 46-48$.

CURRAN, C.E. 1982. Religion, law and public policy in America. Jurist, 42:14-28.

DE BLOIS, M. 1981. Abortus en artikel 2 van de Europese Conventie voor de rechten van de mens. Nederlands Juristenblad, 56(6):141-150.

DEL VECCHIO, G. 1969. Man and nature. (Vertaal deur A.H. Campbell) Notre Dame : University of Notre Dame Press.

DELVIN, P. 1965. The enforcement of morals. Oxford : Oxford University Press.

DUVENAGE, B. 1971. Abortus Provocatus vanuit etiese gesigspunt. Bulletin van die Suid-Afrikaanse Vereniging vir die bevordering vaan Christelike wetenskap, 30:14-33.

ELLIS, R.H. 1974. The free churches. (In Oosthuizen, G.C., ed. The great debate: abortion in the South-African context. Kaapstad : Timmins. 41-47.)

FERREIRA, M. 1985. Abortion and family planning: a literature study. HSRC Repor S-126. Pretoria : HSRC.

FULLER, L. 1958. Positivism and fidelity to law - a reply to professor Hart. Harvard Law Review, 71(4):630-672.

GLENN, G.D. 1975. Abortion and inalienable rights in classical liberalism. American Joumal of Jurisprudence, 20:62-80.

COLEMBO, R. 1985. Scandal of the gymslip mums. Sunday Times: 7, Aug. 8.

HABERMAS, J. 1974. Theory and practice. (Vertaling J. Vicrel) London : Heinemann.

HALL, R.E. 1970. Abortion. (In Hall, R.E., ed. Abortion in a changing world. New York : Columbia University Press. p. 137-156.)

HART, H.LA. 1958. Positivism and the separation of law and morals. Harvard Law Review, 71(4):593629.

HART, H.LA. 1961. The concept of law. Oxford : Clarendon Press.

HEYNS, JA. 1985. Teologiese etiek. Pretoria : NG Kerkboekhandel.

HUMBER, J.M. 1976. Abortion. (In Humber, J.M. \& Almeder, R.F., ed. Biomedical ethics and the law. New York: Plenum Press. p. 71-81.)

HURLEY, D. 1974. Abortion in Roman Catholic tradition and contemporary discussion. (In Oosthuizen, G.C., ed. The great debate: abortion in the South African context. Kaapstad : Timmins. p. 70-77.)

KOLB, C.E.M. 1981. The proposed human life statute: abortion as murder? American Bar Association Joumah, 67:1122-1126.

KUNST, J. \& MEIRING, R. 1984. Abortion law - a need for reform. De Rebus, 264-266.

MIDDLETON, AJ. 1972. Abortion. De Rebus: 397.400.

MILL, J.S. 1859. On liberty. (In Mill, J.S. Three essays. London : Frowde. p.5-141.)

NADVI, S.S. 1974. Islamic approach to abortion. (In Oosthuizen, G.C., ed. The great debate: abortion in the Sout African context. Kaapstad : Timmins. p. 48-49.)

OOSTHUIZEN, G.C. 1974. Termination of pregnancy. (In Oosthuizen, G.C., ed. The great debate: abortion in the South African context. Kaapstad : Timmins. p. 60-66.)

RA7 J. 1979. The authority of law: essays on law and morality. Oxford : Clarendon Press.

RAAD VIR GEESTESWETENSKAPLIKE NAVORSING, 1980. Sckere houdings jeens aborsie. Navorsingsbevinding S-N-221. Pretoria : ISODEM. 
REFORMED ECUMENICAL SYNOD. 1983. RES testimony on human rights. Grand Rapids. Michigan.

RES

kyk

REFORMED ECUMENICAL SYNOD

SARVIS, B. \& RODMAN, H. 1974. The abortion controversy. New York : Columbia University Press.

SCHWðR, T.G., OLIVIER, J.A. \& LOUBSER, J.D. 1984. Die ABC van geregtelike geneeskunde. Pretoria : HAUM

SIBISI, H. 1974. Abortion and Zulu culture. (In Oosthuizen, G.C., ed. The great debate: abortion in the South African context. Kaapstad : Timmins. p.53-59.)

STEENBERG, N.J.P. 1985. Aborsie: die gevolge. Die Kenkbode, 137(25):5. Jun. 19.

STEINEM, G. 1981. The ultimate invasion of privacy. Ms, IX:43-44.

SUAREZ, F. 1613. Tractatus de legibus ac deo legislatore. Antwerpen.

TARR, A. 1983. The christian view of abortion. New Vision: 16-19. Sept. - Oct

THOMAS VAN AQUINO. 1977. Summa theologica. Koln: Verlag Styria.

TOTH, R.S. 1985. The plain truth about abortion - why so little understood? Plain Truth, 50(4):2-4; 42 43.

VAN DER VYVER, J.D. 1983a. Law and morality. (In Kahn, E., ed. Fiat justitia - essays in honour of Oliver Deneys Schreiner. Kaapstad : Juta. p. 350-369.)

VAN DER VYVER, J.D. 1983b. The right to life of the unborn in South African law. (In Kahn, E., ed The sanctity of human life - Senate special lectures. Johannesburg : University of the Witwatersrand. p. 6-12.)

VAN DER VYVER, J.D. \& JOUBERT, DJ. 1985. Persone- en Familiereg. Kaapstad : Juta. (Tweede uitgawe.)

WALLIS, C. 1985. Children having children. Time, 126(23):38-49. March.

WEISS, A. 1974. The Jewish attitude to abortion. (In Oosthuizen, G.C., ed. The great debate: abortion in the South African context. Kaapstad : Timmins. p. 31-40.)

WILLIAMS, G. 1958. The sanctity of life and the criminal law. London : Faber \& Faber.

HOFSAKE

S v King 19712 PH H103(T). 
